\title{
Animalidade e apostasia da vontade: Nietzsche vê Schopenhauer
}

\author{
Animality and apostasy of the will: Nietzsche looking at Schopenhauer
}

\section{Saulo Krieger}

Resumo: O objetivo deste artigo é fazer ver de que modo o caráter de Janus - do mito de Janus - da filosofia de Schopenhauer pautou a relação que com ela entabulou a filosofia de Nietzsche -, aspecto este um tanto relegado pela pesquisa Nietzsche, talvez justamente por se tomar a relação entre ambos como exaurida em binômios do tipo "adesão e ruptura", "encantamento e distanciamento crítico", "pessimismo e afirmação da vida". Assim sendo, num primeiro momento preliminar procederemos a analisar a face dual da filosofia de Schopenhauer, cujo olhar se volta simultaneamente ao passado e ao futuro. Num segundo momento preliminar visitaremos a ousadia de Schopenhauer ao converter as ambições malogradas da filosofia (na figura da "coisa em si") no princípio inconsciente da vontade. A partir daí passaremos à compreensão de Schopenhauer por Nietzsche ao modo de um filósofo que, vitimado por sua segunda natureza, alemã, esquiva-se de protagonizar a filosofia trágica, que chegou a tangenciar, em função do esquadrinhamento metafísico de sua arrojada descoberta - o inconsciente na espécie humana.

Palavras-chave: Metafísica; Inconsciente; Vivência; Trágico

Abstract: The purpose of this article is to clarify how the Janus face of Schopenhauer's philosophy guided the relation between Nietzsche and the author of The World as Will and Representation. This aspect has been neglected by the Nietzsche research, perhaps judging this relation as a topic exhausted in pairings such as "adherence and rupture", "enchantment and estrangement", "pessimism and life affirmation". That said, at a first preliminary moment we will analyze the dual face of Schopenhauer's philosophy, with his gaze simultaneously towards past and future. At a second preliminary moment, we will approach Schopenhauer's daring attitude of converting philosopher's failed ambitions (thinking, of course, on the thing-in-itself) on the unconscious principle of the will. From them on, we are going to tackle Nietzsche's grasp of Schopenhauer as a philosopher who, vulnerable to his second nature, a German nature, avoid featuring the very tragic philosophy that he reaches to touch, in the favor of a metaphysical treatment of his audacious discovery - the unconscious in human species.

Keywords: Metaphysics; Unconscious; Personal experience; Tragic

\footnotetext{
* O presente trabalho foi realizado com o apoio da Capes (Coordenação de Aperfeiçoamento de Pessoal de Nível Superior), entidade do Estado brasileiro voltada à pesquisa e ao desenvolvimento científico.

* Doutor em Filosofia pela Universidade Federal de São Paulo, com estágio bolsa-sanduíche CAPES na Université de Reims Champagne-Ardennes. E-mail: saulokrieger@hotmail.com
} 


\section{Entre a metafísica e o inconsciente: Schopenhauer e suas duas faces de Janus}

Nietzsche foi um atento observador do que os outros filósofos ocultavam, de como ocultavam e do modo como o elemento ocultado havia impelido a filosofia até ali. Isso, o que surpreende, independentemente de os ter lido de maneira direta ou por algum manual de história da filosofia, como o de Kuno Fischer. Foi assim que já os gregos "ocultavam seu afeto agonal, decorando-se como 'os mais felizes' por meio da virtude” (26 [285], verão outono de 1884) ${ }^{1}$. Foi assim que Sócrates ocultou seu pessimismo esgrimindo os círculos aristocráticos de Atenas (cf. 26 [285], verão - outono de 1884). Foi assim que Leibniz, Kant, Hegel e Schopenhauer hipocritamente ocultaram sua segunda natureza, a alemã (cf. 26 [285], verão - outono de 1884). Nesse sentido, num fragmento redigido em algum momento entre os anos de 1885 e 1886, ${ }^{2}$ o autor do Zaratustra observa a existência de pensamentos de fundo por trás de posições filosóficas. E assim, e Nietzsche aí tem em mente sobretudo Kant, Hegel e Schopenhauer, por trás de posições assumidas, no âmbito de uma vontade de verdade, de uma historicização ou de um pessimismo, que para Nietzsche constituiriam um filosofar de segunda ordem, haveria outra vontade, de fundo, a vontade de, afinal e em primeiro lugar, viver (“ich will erst leben”, cf. 2 [161], outono de 1885 - outono de 1886). A filosofia que se pautou diretamente por essa vontade de fundo, trazendo-a à tona e protagonizando um "filosofar de primeira ordem", seria assim a de Nietzsche. Pois é entre um e outro filosofar, de segunda e de primeira ordem, que assoma o objeto do qual vamos tratar aqui, a figura híbrida e intrigante de Schopenhauer. Acreditamos que ainda há algo ou mesmo muito a se dizer em se tratando da relação de Nietzsche com um Schopenhauer que ele teria visto como um ponto de inflexão. Como aquele que, tendo deparado com sua própria animalidade, correu a refugiar-se na metafísica.

Ao conceber fins inconscientes (cf. 7 [211], primavera-verão 1883) ao tempo mesmo em que dá vazão a suas pretensões sistemáticas e metafísicas, Schopenhauer de fato vem a ser um ambíguo ponto de inflexão. Christopher Janaway, citando Adorno, aponta

\footnotetext{
${ }^{1}$ As citações das obras de Nietzsche e referências a elas, porque aqui estruturantes e abundantes, serão apresentadas no corpo do texto, e segundo o seguinte padrão: para seus fragmentos póstumos, numeração e período aproximado de sua escrita (p.e., "26 [285], verão - outono de 1884". Para o caso das obras, serão sempre referidas pela sigla convencionada do original em alemão e do português, sucedida no número do aforismo. Assim, para O nascimento da tragédia, GT/NT (p.e., GT/NT Prefácio § 3); para Miscelânea de opiniões e sentenças diversas, VM/OS (p.e., VM/OS § 5); para Aurora, M/A; para A gaia ciência, FW/GC; para Para além de bem e mal, JGB/BM; para Ecce homo, EH/EH. Quando o texto de Nietzsche for apenas referido, e não expressamente citado, a citação verá antecedida de "cf.". As traduções dos textos de comentadores reproduzidas nas notas de rodapé são livres e de nossa autoria.

2 "Eu estava mais a atentar para o fato de que jamais surgiu um ceticismo ou um dogmatismo em teoria do conhecimento sem pensamentos de fundo, - [eu estava a atentar] para o fato de que eles têm um valor de segunda ordem, enquanto bem se pode questionar sobre o que, no fundo, estaria a forçar essa posição: [passei a atentar] mesmo para a vontade de certeza, sobre se esta não seria a vontade de 'em primeiro lugar, quero viver"” (2 [161], outono de 1885 - outono de 1886).
} 
Schopenhauer como "ancestral rabugento da filosofia existencial e herdeiro perverso dos grandes especuladores" 3 . E da filosofia de Schopenhauer, Sebastian Gardner ressalta a "posição como de Janus na história do pensamento. Ela se põe na junção de duas correntes originalmente unidas do Iluminismo, e justamente no momento de sua separação final: entre o humanismo racionalista e o naturalismo científico" ${ }^{4}$. Ao humanismo racionalista Schopenhauer seria fiel em razão de sua metafísica; ao naturalismo, pelo fato de essa metafísica ser da experiência. Mas mesmo para nossos propósitos aqui, Schopenhauer se assoma como ambíguo ponto de inflexão. Nesse sentido, adotando a feliz alegoria proposta por Gardner, uma das faces do Janus-Schopenhauer estaria voltada para um filosofar que, sim, reconhece a ação inconsciente no pensamento. Reconhece que a filosofia já não mais poderia simplesmente contorná-lo como se ele não estivesse ali, a atuar. Reconhece também que a "essência" do homem não lhe é exclusiva, e muito pelo contrário. Reconhece, ainda, que o inteiro âmbito outrora reconhecido como "das paixões”, que supostamente poderia ser dominado pelo âmbito da razão, ${ }^{5}$ na verdade remeteria a algo de muito mais amplo e mais profundo, e que ele denominará "vontade”. Em relação ao império de tal vontade, o intelecto, com suas representações e seus conceitos, é um reino à parte, e sobretudo é mero instrumento. Por essa mesma face de Janus, Schopenhauer antecipou Freud de maneira notável, já intensamente pesquisada, além de reconhecida, como o foi ao menos em parte, pelo próprio Freud ${ }^{6}$. Acresça-se ainda que por certo sem essa mesma face de Janus a filosofia de Schopenhauer não teria sido tão sedutora a Nietzsche, sendo provável que não fosse ela a patrocinar a passagem da filologia para a filosofia.

Fazendo jus ao mito de Janus, por outro lado, por outra de suas faces Schopenhauer tem olhos fixos no passado, a ele se identifica e deseja preservá-lo. É a face pela qual o filósofo de Frankfurt se mantém um filósofo sistemático. E é também um filósofo que propõe uma concepção integralmente metafísica de mundo, a despeito da crítica kantiana, que reduzira drasticamente as pretensões e o escopo da metafísica. Essa outra face de

\footnotetext{
${ }^{3}$ Cf. JANAWAY, Introduction. In: JANAWAY, C. The Cambridge Companion to Schopenhauer, p. 1

${ }^{4}$ Cf. GARDNER, Schopenhauer, Will and the Unconscious, p. 404.

${ }^{5}$ Há que se fazer menção ao crucial interregno representado pela filosofia kantiana, já que Kant tratou em pé de igualdade os âmbitos da razão e da paixão, concedendo a cada qual uma de suas Críticas.

${ }^{6}$ São diversas as menções de reconhecimento a Schopenhauer por Freud, sobretudo em obras e escritos da maturidade - a exemplo do que se tem nos Três ensaios sobre a teoria da sexualidade (1905), em A história do movimento psicanalítico (1914) e "Uma dificuldade no caminho para a psicanálise" (1917), quando esmoreciam as preocupações cientificizantes do fundador da psicanálise, dando lugar ao cabedal literário e filosófico que sempre a permeou. Sobre a relação de Freud com Schopenhauer, cf., entre outras contribuições, as seguintes obras seminais acerca desse tema: ASSOUN, Freud - La Philosophie et les Philosophes, p. 177-218, e GÖDDE, Traditionslinien des "Unbewußten" - Schopenhauer - Nietzsche - Freud, p. 384-461.
} 
Janus atua como um contrapeso ao que em Schopenhauer há de arrojo e de inovação. Afinal de contas, como já referimos, sua concepção de vontade pode e deve ser entendida como uma formulação do inconsciente, já que a vontade atua em nós sem que disso tenhamos controle ou consciência. Não obstante, a essa concepção Schopenhauer confere todo um tratamento metafísico. Pretende pautá-la por delimitações precisas em relação ao que ela não é, ou seja, por uma oposição estanque ao que é do domínio da representação, da cognição, das relações causais. Justamente por isso, não permite que objeto aparentemente tão afinado aos apetites, e por isso mesmo incontrolável e deletério, venha a impregnar a sua filosofia. Se divide o mundo em vontade e representação, não é à vontade que vai se perfilar ou a ela se fundir. Não é à vontade que se reconhece e a ela se identifica. Muito menos a vivencia. E ao lhe atribuir caráter sobranceiro, de dispositivo de decifração de mundo, esse viés metafísico mantém-na a distância, impede que ela se aproxime do cerne em que ela habita e pulsa - seja no animal, no homem, no próprio Schopenhauer. Impede ainda que sua filosofia efetivamente "se naturalize", "se animalize" (cf. 9 [178], outono de 1888), como impede que sua própria generosidade, o sacrifício de si mesmo à filosofia (cf. M/A § 459) seja a protagonização de um filosofar.

\section{Subversão da coisa-em-si em princípio inconsciente}

Schopenhauer entabula o hibridismo de sua filosofia à medida que, no menos vivencial dos temas do menos vivencial dos filósofos, ele encontra o seu ponto de inflexão e referimo-nos aqui a Kant e à coisa-em-si. Ele o faz apontar bem na direção oposta à do enquadramento kantiano. Se acima referimos que filósofos pós-kantianos atentaram mais à coisa-em-si do que o próprio Kant, e se os idealistas, para lhe darem conta ou para negála, procederam a um longo percurso, Schopenhauer propõe para ela um acesso, desvelando-a de maneira física, experimental e brusca. Algo inédito na história da filosofia, põe-se o corpo como via de acesso à metafísica. Quanto a esse aspecto, Schopenhauer se opõe radicalmente a Kant, que só conseguia antever uma metafísica $a$ priori, de todo apartada da experiência. Schopenhauer conceberá uma metafísica como empírica, a posteriori, a sua base empírica lhe sendo proporcionada pelo corpo, que se dá a um só tempo como representação (pela via exterior) mas também como vontade (pela via interior). O próprio Schopenhauer assinala a sua recorrência ao corpo como "o percurso mais original e mais importante de minha filosofia, a saber, a passagem, declarada impossível por Kant, do fenômeno à coisa em si” (W II, 239). Assim, se a experiência metafísica até então sempre fora associada a um voo ao abstrato, ao imaterial e inefável, o modo como Schopenhauer vai trazê-la para seu extremo oposto será concebendo-a como "uma via subterrânea, uma ligação secreta que, por uma espécie de traição, nos introduzirá na fortaleza contra a qual vêm ecoar todos os ataques que lhe são dirigidos de fora” (W II, 245). 
Com a referida "ligação subterrânea", secreta, Schopenhauer como que implode dicotomias em vigor na filosofia desde Platão e seus mundo das ideias e mundo sensível, a que se sucederam espírito e corpo, res cogitans e res extensa, fenômeno e coisa-em-si. Pois o autor de $\mathrm{O}$ mundo como vontade e representação toma de assalto a coisa-em-si, reconhecendo-a pelo que há de mais íntimo no corpo, no movimento do corpo, pela ação da natureza no homem, afirmando que tal determinação já estaria em germe na própria filosofia de Kant: "Kant não foi até o fim com seu pensamento: eu apenas levei a bom termo o seu trabalho. [...] O que Kant fala tão-só do fenômeno humano, eu o transmiti a todos os fenômenos em geral, que se diferenciam do humano apenas em grau” (W I, 623, trad. ligeiramente modificada) ${ }^{7}$. E especulativamente procura garantir, "eu, de fato, assumo, embora não o possa demonstrar, que Kant, todas as vezes em que falava da coisaem-si, na profundeza mais escura de seu espírito sempre pensava, já, de forma indistinta, na vontade” (W I, 628, trad. ligeiramente modificada). E se como que implode uma dicotomia que acabava de se desdobrar, no filósofo de Königsberg, como fenômeno e coisa-em-si, é porque reconhece uma instância em que a experiência de um e de outra se faz possível:

o corpo é dado de duas maneiras completamente diferentes: uma vez como representação na intuição do entendimento, como objeto entre objetos e submetido às leis destes; outra vez de maneira completamente outra, a saber, como aquilo conhecido imediatamente por cada um e indicado pelo termo VONTADE (W I, 157).

O princípio da "vontade", tem menos que ver com a vontade segundo a filosofia de até então e o senso comum (que obviamente comportam a representação de fins), e mais está relacionado a um impulso que nos impeliria, em nossas representações e nas próprias ações intencionais, sem que dele nos fizéssemos conscientes. Desse modo, a própria atitude de isolar do intencional, do motivacional, um princípio que estaria além de todo o representacional e de todo o fenomênico já não poderia, ao menos não sem brechas, ter pretensões a um todo sistemático. Isso porque a atitude em questão faz-se, assim, reconhecidamente movida por algo que está fora dela e não se deixa registrar, pois é alheia a toda a forma de representação. Por mais que Schopenhauer privilegie o acesso direto, imediato e experimental à vontade, como em seu exemplo do movimento do braço, esse “conhecimento de origem” não esgota a pletora de questões referentes à nossa relação com a vontade. Tal relação, se não for vista do ponto de vista unificador e simplificador da metafísica, que é o de Schopenhauer, revela-se toda ela mediação e representação.

\footnotetext{
${ }^{7}$ Façamos constar que as passagens de o Mundo como vontade e representação referentes ao segundo tomo (Zweiter Band), foram consultadas no original e assim são citadas, em edição de 1913, conforme as duas notas imediatamente acima. As passagens referentes ao primeiro tomo foram consultadas e são citadas segundo a tradução brasileira.
} 


\section{Crítica de Nietzsche à ideia de vontade em Schopenhauer}

É bem nesse sentido que se dá a crítica de Nietzsche ao papel atribuído à vontade na filosofia de seu educador. O ponto de partida para o próprio Nietzsche pensar a vontade é, evidentemente, schopenhaueriano ${ }^{8}$. O que já não é tão evidente vem a ser em que medida a sua concepção de vontade e, logo, de vontade de potência se manterá sob o escopo de Schopenhauer ${ }^{9}$. Filiações à parte, as quais têm o condão de relativizar, mas não de invalidar o teor das críticas de Nietzsche ao filósofo de Frankfurt, o caso é que ele negará à vontade o fator proeminência - e o concederá ao sentimento de potência -, como negará à vontade - que circularmente será “quebrada”, tornando-se vontade de sua própria potência qualquer conotação metafísica. O autor do Zaratustra, por certo que levando em conta a processualidade, variação e mobilidade implicadas pelo darwinismo, observa que uma consequência espantosa de todo o enquadramento darwiniano - pois Darwin não é meramente uma teoria a mais - estaria em pôr em questão todas as qualidades que tomamos por eternas. A metafísica desde sempre se valeu de um ou outro princípio, qualidade eterna, para com ele, devidamente posicionado num plano ressalvado das intempéries fenomênicas, ajustar-se a todos os fenômenos, a objetivar um mundo desordenado e aparentemente arredio. Ocorre que a vontade de Schopenhauer, que se pretende um tal princípio, para Nietzsche "não se objetiva adequadamente” (19 [132], verão

\footnotetext{
${ }^{8}$ Deve-se fazer constar a amplitude do fascínio que Schopenhauer exerceu sobre o autor d'O nascimento da tragédia, mesmo o chamado à filosofia que seu $O$ mundo como vontade e representação teria representado ao jovem Nietzsche. Naturalmente que isso diz respeito também - ou mesmo sobretudo - à questão da vontade. É o próprio jovem filósofo que relata esse poder de atração em seu "Retrospectiva sobre meus dois anos em Leipzig"” (Rückblick auf meine zwei Leipziger Jahre), do outono de 1867. Ele conta ali como, em 1865, num alfarrábio em Leipzig, de repente se defrontou com um exemplar de $O$ mundo como vontade e representação: "tomei-o nas mãos, como objeto que me era completamente estranho e o folheei. Não sei qual demônio me soprou nos ouvidos: 'Leve este livro para casa'. De todo modo, foi algo que contrariou meu hábito de não ir com muita pressa na compra de livros. Em casa, com o tesouro adquirido, lancei-me no sofá e comecei a deixar aquele gênio energicamente sombrio atuar sobre mim. Ali se tinha cada linha, cada renúncia, cada negação, cada resignação a gritar, ali eu olhava num espelho no qual eu contemplava o mundo, a vida e a própria alma em desconcertante grandiosidade. [...] A necessidade de autoconhecimento, mesmo de um autodesfazimento me arrebatava com violência; testemunhas daquela reviravolta ainda me são as inquietas e melancólicas folhas de diário daquele período, com suas inúteis autoacusações e olhares desesperados à purificação e à transformação de toda a humanidade" (NIETZSCHE, Rückblick auf meine zwei Leipziger Jahre. In: Werke. Kritische Gesamtausgabe, p. 513, em livre tradução).

${ }^{9}$ Para uma abordagem que vê a concepção de vontade de potência por Nietzsche, sobretudo em seu aspecto cosmológico (o outro aspecto seria o psicológico), como essencialmente um legado schopenhaueriano abordagem que é, ademais, crítica à crítica de Nietzsche a Schopenhauer -, cf. SOLL, Schopenhauer as Nietzsche's 'Great Teacher' and 'Antipode', p. 177-184, em especial p. 177, 179.
} 
de 1872 - início de 1873$)^{10}$. De fato, a vontade ali é menos um apetite a reger as ações e representações sob a sua égide, e mais um princípio da natureza que não comporta representação nem cognição. E se não se objetiva adequadamente, também outra ressonância metafísica lhe é negada por Nietzsche: ele afirma que "a vontade não é fato último” (23 [12], final de 1876 - verão de 1877), e isto, contextualize-se, numa época em que ele ainda busca o que será o seu "fato último" e a relação deste com as viscerais noções de prazer e desprazer ${ }^{11}$. Entrando nos escritos da maturidade, quando prestes a apresentar a hipótese de vontade de potência em Para além de bem em mal (1886), o filósofo mais uma vez toma distância da vontade segundo seu mestre e lhe nega um terceiro elemento de proeminência: “a vontade não é fato imediato, como quer Schopenhauer!” (23 [327], verão outono de 1884). Porém antes disso, no período chamado "iluminista" de Nietzsche, ele chega a uma compreensão que não o abandonará: "o grande erro fundamental de Schopenhauer está em não ter visto que o apetite (a "vontade") é apenas um modo de conhecer e nada mais" (47 [5], setembro - novembro de 1879).

As críticas de Nietzsche à vontade em Schopenhauer servirão para delinear o seu fato último - a hipótese de vontade de potência - e para depuradamente conceber sua noção de impulsos. Se se pode dizer que a inspiração filosófica de Nietzsche reside em grande parte no princípio de ação inconsciente de Schopenhauer, para tal fez-se necessário problematizar seu intento, mantendo distância da face metafísica de Janus. Ele entabula profícua relação com Schopenhauer não apenas pelas limitações metafísicas do filósofo de Frankfurt, mas também, de modo mais amplo, pelo que já o próprio Schopenhauer pressente de limitado, de sem-saída no caminho da metafísica. A metafísica prometia o mundo - que ele teria valor, que poderia ser apaziguado e dominado, e o poderia justamente pelo que a filosofia tinha por de maior valor: seus princípios racionais. A metafísica pressupunha Deus, a imortalidade da alma e o mundo, julgou poder prová-lo por seus próprios meios, e com Kant se viu não ser possível demonstrar as respectivas existências. A metafísica julgou possível prover ou resgatar a liberdade do homem, porém

\footnotetext{
${ }^{10}$ Acerca do que pode ser entendido como uma triangulação Schopenhauer - Nietzsche - vontade, Ivan Soll afirma: "It is this Schopenhauerian notion of the will [the will is the true being of everything in the world] as the primary function of the mind that underlies Nietzsche's psychological theory of the will to power as the deep motivation of all human behavior. But in this as in other matters, Nietzsche takes an idea from Schopenhauer and adapts it to his own purposes" "“É essa noção schopenhaueriana da vontade [a vontade como ser verdadeiro de todas as coisas no mundo] como função primária da mente que subjaz à teoria psicológica de Nietzsche da vontade de potência como motivação profunda de todo comportamento humano. Mas nesta como em outras questões, Nietzsche toma uma ideia de Schopenhauer e a adapta a suas próprias finalidades") (Idem, p. 179).

${ }^{11}$ Mais precisamente, Nietzsche ali antevê o que seria "fato último" justamente na direção da adequação de uma vontade - mas uma vontade real, plural, individualizada não como princípio metafísico - nos organismos, que se daria por prazer e desprazer, e sim mais precisamente como busca do prazer, fuga ao desprazer (cf. 23 [12], final de 1876 - verão de 1877).
} 
essa pretensão igualmente caiu por terra com as antinomias kantianas. E mesmo o sujeito, que em dado momento se assomara como garante de toda a construção filosófica, de toda a visão de mundo, juntamente com a noção de alma foi suplantado por sua própria corrente de pensamentos, tornando-se quase uma miragem, oferecendo-se à dissolução. Ocorre que a bem essas instâncias o homem empenhara sua capacidade de desejar, do que resulta, segundo Nietzsche,

esse estar cansado da existência, essa vontade de não mais querer, a destruição da vontade própria, do bem de si mesmo [Eigenwohl], da abnegação (como expressão dessa vontade invertida) - a isso e a nada além Schopenhauer queria saber louvar com a mais elevada honraria (2 [197], outono de 1885 - outono de 1886).

Pouco antes, nessa mesma passagem, com relação a Schopenhauer ele se refere à condição de "estar farto", atrelada à descoberta de o mundo não ter o valor que se acreditava que tivesse, assim como em outro momento fala numa "repugnância" e num "estar farto" por trás de filósofos como Kant e Schopenhauer. Por certo que essa "repugnância” se intensificou sobremaneira na passagem de Kant a Schopenhauer, a ponto de este último se fazer, se continuador daquele, como o foi, um continuador autodeclaradamente audacioso. Ora, com "audacioso", "original”, por outro lado "fiel” ao próprio Kant, se convincente ou não em seus argumentos no tocante a derivar a vontade da coisa-em-si, ${ }^{12}$ quanto a esse ponto pretendemos nos ater precisamente ao movimento que ele assim realiza: o inatingível sendo trazido ao que nos é mais íntimo e imediato, o relegado - a coisa-em-si, de certa forma relegada pelo próprio Kant - vindo a ser colocado no centro da filosofia, o mais alto voo da razão, que se esperaria para se chegar à coisa-emsi, sendo deparado num subterrâneo corpóreo: convincente ou não, Schopenhauer por certo foi desconcertante e tangenciou o trágico: se entendermos a coisa-em-si kantiana como o que não posso conhecer - já que ela está lá sem que se a possa conhecer -, e se para Schopenhauer a coisa-em-si se identifica à vontade, então poderíamos dizer que o que não posso conhecer é a vontade. Essa vontade é justamente a força da natureza que impele todas coisas, como impele a conhecer, por mais que se subtraia à cognição. Mas, justamente, se Schopenhauer fosse menos ou nada metafísico, se admitisse uma transitividade direta do seu conceito de vontade, se admitisse uma vontade de e se aplicasse essa transitividade ao conhecer, como vontade de conhecer, teríamos que o que não posso conhecer é a (a própria) vontade de conhecer ou: por mais que eu conheça, não posso conhecer a vontade que me impele. Ressalte-se que neste arrazoado não introduzimos em Schopenhauer elementos que ali não estão, salvo o que chamamos de "transitividade direta" da vontade - vontade que nele seria

\footnotetext{
${ }^{12}$ Sobre os dois argumentos que provam a viabilidade da passagem da coisa-em-si à vontade, um em cada tomo de O mundo como vontade e representação, cf. JACQUETTE, D. Schopenhauer's Proof that Thing-in-Self is Will, p. 65-108.
} 
mais "intransitiva" ou "intransitiva direta". O que fizemos foi aproximar um tanto as distâncias, procuramos deixar claros os termos da relação e tornar visível o elemento que se fez impossibilitado em se tratando de coisa-em-si - vontade: o conhecer. Chegamos assim a um desacordo, a uma dissonância basilar entre vontade e o mundo; se sobre tal dissonância se funda a filosofia de Schopenhauer, tem-se aí a configuração de uma filosofia eminentemente trágica, que assim não se resolveria nem com edifícios metafísicos, nem com a razão, demandando-se um estrato mais profundo que o do próprio conhecer. Mas há que se conceder que o próprio Schopenhauer não explicitou as mediações tal como o fizemos, e não o fez porque o próprio esquema metafísico o deteve, com a rígida separação entre vontade e representação a impedir de antemão a transitividade da vontade - a vontade de. Assim sendo, no limite Schopenhauer tangenciou o trágico, mas por não protagonizar sua filosofia nem a vontade que ela tematiza, ${ }^{13}$ optou por ser espectador. Com isso, o próprio mergulho na condição trágica se fez preterido pela perspectiva niilista: em vez da dissonância acima delineada, a concordância pela negação: nem o conhecimento nem nada tem valor.

\section{Schopenhauer e sua “segunda natureza”, alemã}

Da vontade não transitiva, ou seja, de uma questão de conteúdo da filosofia de Schopenhauer, para a questão da transitividade com sua própria filosofia: por mais que Schopenhauer tenha dedicado a sua vida à filosofia (M/A, § 459), ele não a vivenciou. Por mais que fosse de sua singularidade, de sua constituição se dedicar, mesmo se sacrificar por uma causa, por um ofício, pela filosofia -, tudo se passa como se tal fosse impedido, interditado por uma segunda natureza, que não incide apenas em Schopenhauer, mas também em Leibniz, em Kant em Hegel (cf. 26 [285], verão-outono de 1884): eles compartilham da natureza alemã, do tipo alemão, e este produz uma interferência comum, responsável por sua hipocrisia - hipocrisia oriunda da interceptação e sequestro, por tal "segunda natureza", da vivência que suas singularidades de outro modo expressariam; hipocrisia oriunda da solução de compromisso pautada por um tipo compartilhado, que os faz denegar de sua própria profundidade. Isso significa que aqui deparamos novamente com a ideia de tipo.

A teoria dos tipos em Nietzsche é própria de uma filosofia que recusa a unidade, o esquema atomista e seus resquícios, em nome de uma pluralidade radical, e de correspondências múltiplas, não unívocas, nem excludentes. É domínio de uma filosofia

\footnotetext{
13 Tal é a temática do aforismo 459 de Aurora, onde se lê: "Rousseau e Schopenhauer - ambos foram orgulhosos o bastante para inscrever em sua existência esta divisa: vita impendere vero [consagrar a vida à verdade]. E ambos, também - como devem ter padecido em seu orgulho, por não conseguirem verum impendere vitce [consagrar a verdade à vida]! - verum [verdade], como cada um deles entendeu - por suas vidas terem corrido junto a seu conhecimento, como um baixo caprichoso, que não quer corresponder à melodia!”.
} 
que, ao analisar a filosofia de até então, desvela nos filósofos intenções insuspeitadas por eles próprios. Desvela a ação defensiva disfarçada de estritamente racional. Desvela a inclinação fantasiada de neutralidade racional. Também a gregariedade oculta, travestida de rigor impoluto e praticado às claras. Desvela dedicação e sacrifício que não se traduzem em vivência. Desvela, enfim, uma filosofia sem singularidade filosofante. E nisso revelanos também parentescos de natureza e de motivação até então insuspeitadas, como o do "baixo caprichoso" em Rousseau e Schopenhauer (cf. M/A § 459, 538), como o da totalidade dos filósofos unidos pela hipocrisia (cf. 26 [285], verão-outono de 1884, 9 [178], outono de 1887), e o das almas "desapaixonadas" de Kant e Schopenhauer. O que se poderia chamar de uma "alemanidade" cobrou de Kant uma filosofia sem vivência, na qual a mente ativa e laboriosa se ocupa em compensar uma alma ausente (cf. M/A § 481). Se não podia fazê-lo em Schopenhauer, para quem já o contato com sua natureza animal, pulsional, impeliu-o a vagar pelo que Nietzsche chama de "selvageria” (cf. M/A 481), como o impeliu a desvelar os impulsos que ele artificialmente unificou, isolou, observou à distância e chamou de "vontade", se o tipo alemão não pôde obliterar de todo a vivência em Schopenhauer, esse mesmo tipo o fez se posicionar justamente nos antípodas do que aparenta ser a chavemestra para a sua filosofia: em Schopenhauer, a vontade não está em parte alguma.

O “não vivenciar" por Schopenhauer é obviamente abrangente, expressa uma "não vivência" em geral, e é desse âmbito mais geral que vem se refletir em sua filosofia. Isso se constata não apenas em sua teoria da vontade, mas também em sua ética, tal como filosoficamente formulada. A impressão que à primeira vista dela se pode ter parece apontar no sentido contrário. Uma ética fundada num sentimento, na compaixão (Mitleid), como é a sua, poderia sugerir que, além de a compaixão cumprir uma função que viesse a compensar o fato de representação e cognição não terem direito à cidadania no reino da vontade, também a pessoa de Schopenhauer seria profundamente compassiva, a ponto de converter racionalmente essa "vivência”, pela qual, ao que parece, não se pensa em si, mas no outro, para o seu filosofar. Porém Nietzsche não vê assim a invocação da compaixão em sua filosofia. No aforismo 133 de Aurora, procede à distinção entre os homens sem compaixão e os compassivos. Por oposição aos sem compaixão, o compassivo, caso de Schopenhauer, teria a "excitável imaginação do medo", a "fina capacidade de pressentir o perigo", e sua vaidade o faz "se ofender rapidamente"; não está acostumado a "tolerar a dor"; e porque não sofreu, acha injusto que outros sofram; sua "brandura de coração", as "lágrimas fáceis”, que faz questão de não ocultar, para Nietzsche não remetem a uma vivência de fundo, autêntica, mas a vivência propriamente dita lhe seria na verdade "a fria bravura, a indiferença estoica” (M/A § 133). Isso por certo não quer dizer que o critério nietzschiano para o vivencial exclua sentimentos, mas exclui, isto sim, sentimentos e posturas que denunciem uma atitude esquiva aos estímulos da realidade processual circundante: a “imaginação excitável”, o "pressentimento do perigo", a vaidade, o melindre, o não sofrer por ter se esquivado ou por não ter chegado a sentir, já que superprotegido, e, nesse 
sentido, o não contato com o mundo pelo revestimento fácil de uma atitude macilenta. Entenda-se, pois, que uma hipersensibilidade - como a que levou Schopenhauer à sua ideia de compaixão - não é o "contato com a coisa”, com o mundo circundante, mas sim o contrário: uma forma de proteção em relação a ele. E por assim contornar o que não é sentido, o que não é vivenciado, Schopenhauer simplificou reativa e artificialmente processos complexos, tal como fez com a vontade, e num caso como no outro siderou-se na precipitação grosseira da palavra. Com isso, forjou-se uma unidade onde ela jamais se deu; a crença em tal unidade e em tal palavra só é possível àquele que não atenta aos modos fortemente inconscientes pelos quais pensamos e deixamos de pensar em nós (cf. M/A, § 133).

\section{Adesão metafísica e não vivência em Schopenhauer}

Deixando-nos assim guiar pelas observações de Nietzsche, observe-se que já há algum tempo estamos operando simultânea e deliberadamente em dois registros: o da exposição, por Schopenhauer, de sua própria filosofia, e o da vivência, ou não, por ele próprio, de seu filosofar. Esse duplo registro se dá por estarmos tratando de Schopenhauer objeto de crítica por Nietzsche, por um lado, e, por outro, pelo fato de o viés de crítica se dar pelo eixo da vivência (Erlebnis). Por uma questão de recorte, esse eixo, eleito uma vez que fecundo dispositivo de conexão entre os dois filósofos, vai obnubilar outros eixos no entanto possíveis, como também, num registro mais amplo, deixa de parte a evidente e maiúscula contribuição do filósofo de Frankfurt para a filosofia de Nietzsche. A crítica de Nietzsche a Schopenhauer, seja dito e ressaltado, não deve ser confundida com uma arrematada desqualificação, pelo primeiro, da obra de seu educador. Deve ser vista, isto sim, como um ricocheteio após um movimento de forte atração, mesmo de chamado à filosofia. O ricochetear, nesse caso, seria a detecção, pelo autor do Zaratustra, de uma oscilação e ambiguidade de Schopenhauer ante seu próprio arrojo, ante a sua própria descoberta, e isto no contexto - se se quiser pensar num contexto mais amplo - de uma interpretação e de uma crítica da cultura europeia. A cultura europeia, bem entendido, uma vez que dominada pelo racionalismo socrático-platônico, que depois se tornara cartesiano e iluminista, e uma vez que assolada pela moral ascética cristã, fizera-se infensa ao contato com a sua própria instintualidade, com sua própria experiência, e isto equivale a dizer, com suas próprias vivências. Se em seu bojo se intentara proporcionar ao homem "o máximo de prazer e o mínimo de desprazer possíveis” (FW/GC, § 12), deixava-se esse mesmo homem sem estofo para fazer frente às consequências do desencanto pela estrita racionalização do mundo (pessimismo, niilismo). Esse estofo, se por óbvio não é de caráter transcendente ou metafísico, é, justamente, vivencial. A oscilação e ambiguidade de Schopenhauer vão se dar em relação à sua descoberta, mas também, de modo mais amplo, 
em relação ao quadro vivencial que tal descoberta - a vontade como aspecto essencial e inconsciente de tudo o que existe - parecerá demandar.

Se a filosofia do século XVIII não reconhecera a diferença entre vida e existência, nesse próprio e mesmo século XVIII, como efeito do advento de um modo de vida burguês, no vácuo de uma constante secularização e da Revolução Francesa, num movimento de reação ao desvelamento de mundo da Aufklärung, todo um campo de experiências ou de vivências privadas passa a cada vez mais se fazer fonte de inspiração e expressividade para os poetas ${ }^{14}$. Para os poetas do Sturm und Drang, a "vida vivida" se tornava o cerne de uma verdade cunhada individualmente, com a vida sendo ali compreendida como vivência, como destino pessoal, como um caminho de vida estritamente individual ${ }^{15}$. Ao modo como a noção de vivência em dado momento passa a se evidenciar pode bem se atentar considerando-se o modo como o termo aparece e se transfigura, passando do designar da ação ao da atenção e da reflexão: Erlebnis, vivência, advém de uma substantivação do verbo erleben, vivenciar; daí se ter a sua substantivação em Erleben (o substantivo em língua alemã se diferencia pela inicial maiúscula) e então em Erlebnis, ambos a denotar vivência com base num distanciamento crítico relativamente a uma ação (erleben) - e o distanciamento é suscitado por condições sociais, econômicas e culturais, às quais a expressividade poética se fez sensível antes do debate filosófico. Ocorre que em 1827 o termo aparecerá já pela pena de um filósofo, quando em uma carta Hegel lhe faz menção em referência a um acontecimento pessoal: "toda a minha vivência [meine ganze Erlebnis]"16. A partir daí, lentamente o termo granjeará a dimensão filosófica que não obtivera no século XVIII, e que cumulará com a atenção que lhe confere Wilhelm Dilthey, no uso biográfico que dele faz ao tratar de Schleiermacher, como dos grandes poetas alemães ${ }^{17}$. Pois entre a menção de Hegel e o tratamento que lhe dará Dilthey se tem a reflexão de Nietzsche e o modo como a questão da vivência se fará crucial ao seu próprio filosofar, e isto inclui a maneira como vê tanto os alemães em geral quanto os filósofos alemães que o antecederam, em especial Kant e Schopenhauer.

Tendo sido engendrada, a exemplo de tantos termos, como uma reflexão a partir de uma ação, a noção de Erlebnis assinala a atenção de uma subjetividade ao que lhe acontece, ou seja, não se trata apenas de viver ou passar por algo, mas de atentar ao que se vive, ao que se experimenta. Isso redundará necessariamente em autorreflexividade? A ver. Pelo modo como é haurida dos românticos, a vivência (Erlebnis) compreende três traços

\footnotetext{
14 Cf. SCHENZ, Erlebnis und Bildung. Die Bedeutung des Erlebens und des Erlebnisses in Unterrichts- und Erziehungsprozessen, p. 16.

${ }^{15}$ Ibidem.

${ }^{16}$ Cf. VIESENTEINER, O conceito de vivência (Erlebnis) em Nietzsche. Gênese, significado e recepção, p. 142.

${ }^{17}$ A referência aqui é à sua obra Das Erlebnis und die Dichtung: Lessing, Goethe, Novalis, Hölderlin (A vivência e a poesia: Lessing, Goethe, Novalis, Hölderlin), publicada em 1906.
} 
principais $^{18}$ : pelo primeiro, ela apresenta o caráter de ligação imediata com a vida; o segundo lhe é a intensidade, e uma intensidade sentida a ponto de transformar a existência, de convertê-la em significabilidade; o terceiro traço é o da impossibilidade de se determinar racionalmente o conteúdo do que se vivencia, de modo que a vivência, assim, será sempre pensada de um ponto de vista estético ${ }^{19}$. Esses três traços, mas sobretudo o terceiro, fazem-se marcas da literatura alemã, do Sturm und Drang ao romantismo. O que se passa desde o Sturm und Drang é precisamente - e já o dissemos acima, quanto à atenção às vivências privadas - uma reação à frieza do racionalismo da Aufklärung, ao predomínio pretensamente inconteste da abstração do entendimento. E em sentido contrário ao da Aufklärung, a evidenciação da vivência é a tradução - seja poética, literária ou filosófica - de um anseio por uma ligação com o infinito, com a Totalidade. Evidentemente que se tem aí um movimento compensatório ao desvelamento de fatos naturais isolados e brutos provido pela ciência iluminista, uma reação ao desencantamento do mundo, travejado em insípidas relações causais.

Dado esse quadro histórico, é com a carga semântica assim sugerida que o autor do Zaratustra recebeu a noção de vivência (Erlebnis). Na pesquisa Nietzsche já se fez ver que, até a altura da Quarta consideração extemporânea, dedicada a Richard Wagner, o filósofo se vale do termo bem no sentido que herdara da tradição romântica e panteísta alemã, com a Erlebnis pensada estritamente segundo os três traços acima assinalados ${ }^{20}$. À altura do ciclo do Humano, demasiado humano (1878-1880) sucede um congelamento dos ideais românticos e metafísicos, ${ }^{21}$ como das crenças e pretensões que lhe vêm atreladas. Quanto aos destinos da questão da vivência, o momento é de transição: o instintivo ainda é visto como submetido ao intelecto, o inconsciente ao consciente, o pulsional sendo objeto de um tratamento atomizado. Essa hierarquia teria de ser - e será - subvertida. E de fato, com a gradual compreensão das interações pulsionais levada a efeito a partir dali e ao longo da década de 1880, a questão da vivência, se se mantém a assumir relevos, é transposta: de equacionada a um Eu sobranceiro e consciente, a ansiar pelo Todo e pelo infinito, a vivência passa a ser remetida à vida orgânica, a uma miríade radicalmente plural de

\footnotetext{
${ }^{18}$ Cf. VIESENTEINER, op. cit., p. 142-143.

${ }^{19}$ E o Nietzsche que se encontra desde sempre impregnado da recepção dessa noção de vivência conceberá e vivenciará - o artístico a mediar conhecimento e vivência, tanto que em um fragmento póstumo ele afirmará, com relação à experiência estética: "a tarefa do filósofo é combater todos os elementos temporais de modo consciente - e para tanto deverá se amparar na tarefa inconsciente da arte” (19 [12], verão de 1872 início de 1873). Nessa mesma direção, no ensaio de autocrítica a O nascimento da tragédia ele observará ser o caso de "ver a ciência com a óptica do artista, mas a arte, com a da vida...” (GT/NT, Prefácio § 2).

${ }^{20}$ Cf. VIESENTEINER, op. cit., p. 147.

${ }^{21}$ No capítulo sobre o Humano, demasiado humano em seu Ecce homo, Nietzsche afirmará: "Um erro após o outro [erros referentes à cerrada herança de Richard Wagner e Schopenhauer, às pretensões românticas e metafísicas] é calmamente colocado no gelo, o ideal não é refutado - ele congela...” (EH/EH “Humano, demasiado humano” $§ 1$ ).
} 
sensações, de percepções; essa miríade em última instância remeterá aos impulsos, e isto quer dizer que as vivências serão uma questão pulsional. Desse modo, os traços de imediaticidade, intensidade, acesso pela via estética, que vimos ser aspectos próprios das vivências, incidirão numa lacuna incomensurável - e incomensurável porque as vivências se dão no âmbito pulsional, que entre outras coisas é o do não verbalizável ${ }^{22}$. Já não se tratará de um processo conduzido pela consciência, pois Nietzsche então a reconhece como "último e derradeiro desenvolvimento do orgânico" (FW/GC § 11) e "tiranizada" pelos instintos (cf. FW/GC § 11). A associação das vivências a um âmbito orgânico, do desconhecido e inabarcável, ${ }^{23}$ de uma inconsciência, perdurará ao longo de seu percurso filosófico. Igualmente perdurará o imperativo de a filosofia se valer dessas vivências, por mais que remetam ao insondável, por mais que se prestem mais a um fazer artístico do que a um discurso direto ${ }^{24}$. Também igualmente, a adesão ou não às próprias vivências se manterá um critério para a análise da obra de filósofos alemães como Kant e Schopenhauer. O teor romântico da Erlebnis herdada por Nietzsche manter-se-á de maneira difusa, e congelado sob o filtro da vida orgânica e pulsional que virá a assumir. Esse teor, em seus traços de ligação imediata com a vida, intensidade e impossibilidade de determinação racional, Nietzsche o terá por ausente na filosofia de Schopenhauer, tanto em sua concepção metafísica da vontade quanto em seu alinhamento à representação - em detrimento da própria vontade.

A esse respeito, justamente, se o mundo lhe é vontade e representação, mantivemonos aqui todo o tempo na questão de o filósofo de Frankfurt não se alinhar à vontade, e até agora não contemplamos o modo como, sem mais, alinhou-se à representação. Ocorre que estaria justamente aí o vício de raiz a de antemão impedir que a filosofia de Schopenhauer pudesse ser por ele vivenciada. Com isso já apontamos para a direção da metafísica, e isto significa que o visceral, que é a vontade em Schopenhauer, não poderia "se converter em vivencial” justamente porque o vivencial é fluido, singular e antecede qualquer conceptualização. E se a antecede, não se deixa reter pelo esquadrinhamento metafísico.

22 "O que são, então, nossas vivências? São muito mais aquilo que nelas inserimos do que o que nelas se acha! Ou deveríamos até dizer que nelas não se acha nada? Que vivenciar [erleben] é inventar?” (M/A § 119; tradução ligeiramente modificada).

23 "Por mais longe que alguém leve seu autoconhecimento, nada pode ser mais incompleto do que sua imagem da totalidade dos impulsos que constituem seu ser. [...] que também nossos juízos e valorações morais são apenas imagens e fantasias sobre um processo fisiológico de nós desconhecido, uma espécie de linguagem adquirida para designar certos estímulos nervosos?” (M/A § 119).

${ }^{24}$ Para referências pontuais sobre a relação de Nietzsche com a arte, cf. nota 19 supra. Para um tratamento do modo como o autor do Zaratustra se vale do fazer artístico para incorporar a tarefa inconsciente da arte em sua filosofia e, com isso, vivenciar o seu filosofar, cf. KRIEGER, S. O cerne oculto do projeto nietzschiano: logos versus pathos no ato de filosofar (seções II.IV a II.XII, cap. II, "Da consciência da metáfora à inconsciência do conceito”). Tese apresentada ao Programa de Pós-Graduação em Filosofia da Escola de Filosofia, Ciências Humanas e Letras da Universidade Federal de São Paulo (Unifesp) em abril de 2019. 
Mas justamente aí se pode levar o questionamento ainda mais longe. Por que a vontade, esboço de desvelamento da animalidade no homem, primeira tentativa de naturalizá-lo, antecipação do inconsciente segundo Freud, não foi capaz de solapar por dentro a própria abordagem metafísica de Schopenhauer? Como não foi capaz de fazer implodir a arquitetônica de seu sistema? Esse questionamento tem ainda uma contraface: por que motivo emergiu a vontade, por um lance de ousadia e originalidade de Schopenhauer num “ambiente filosófico" - o do próprio Schopenhauer - que se mostraria tão hostil à sua manifestação?

Em primeiro lugar, o sistema metafísico por si só faria enquadrar seu objeto, mesmo objeto tão renitente e desafeito quanto a vontade: para tanto, bastaria lançar mão da habilidade metafísica de transformar a vontade em "mera palavra vazia" (14 [121], primavera de 1888), passível de designar alguma outra coisa, e valer-se da habilidade conceitual de se aproveitar de uma "lacuna da língua” (VM/OS §5) ou, enfim, bastaria manter a vontade como conceito genérico, como de fato o fez, por isso mesmo passível de ser predicado com algo que o faça negar: "vontade de não mais querer" (2 [197], outono de 1885 - outono de 1886). Mas com isso seria ainda de se perguntar se a abordagem metafísica chegaria a ponto de “quebrar" a vontade própria, fazendo com que se convertesse na expressão de um querer invertido (cf. 2 [197], outono de 1885 - outono de 1886). Daí a questão sobre o caráter "de não vontade" da vontade em Schopenhauer, problema que se revelou tão caro a Nietzsche, demandar que se vá além do enquadramento metafísico a que tal instância foi submetida. A referida questão nos leva a perscrutar especificidades, a considerar não apenas a sua ideia de vontade, mas a própria metafísica de Schopenhauer a encerrar em si o híbrido e o contraditório.

Ora, assim como o intrinsicamente contraditório confere o teor da concepção schopenhaueriana de vontade, que para Nietzsche vimos ser uma "vontade de não mais querer" (2 [197], outono de 1885 - outono de 1886), também em sua metafísica há um teor aparentemente contraditório. Tudo se passa como se o filósofo de Frankfurt fosse movido por um estranho, quase paradoxal misto de voluntarismo e passividade - e também a esse respeito ele protagonizaria um híbrido inédito em filosofia. No caso da herança kantiana, é em grande parte por voluntarismo que ele acessa o inacessível, encontrando-o no âmago de um movimento corpóreo. E o que Schopenhauer desvela na coisa-em-si é a natureza a atuar no ser humano, à revelia dele, indiferente a ele, negando-lhe qualquer teleologia ou providencialidade, antecipando Darwin, o próprio Nietzsche, Freud, o existencialismo. Ocorre que em sua própria filosofia essa mesma vontade alija o homem de si mesmo e da possibilidade de construção de um destino - de seu próprio destino: o homem se vê apassivado ante o impulso que, se concebido sob outras circunstâncias, faria dele um ser sumamente ativo. Restam-lhe atividades embotadas, como estar emaranhado à representação, à razão e à sua própria individuação. Ou então, resta-lhe provisoriamente contornar essa vontade, esquivar-se dela momentaneamente, mediante, ainda uma vez, a 
passividade da contemplação estética - e nesta, diga-se, a atividade da criação artística não se faz incluída nem prevista. E para se compreender esse dispositivo de atitude esquiva, cumpre trazer à baila outra filosofia que, quase tanto quanto a de Kant, permeia o sistema schopenhaueriano, sendo também ela assenhoreada pela dinâmica interna de Schopenhauer: estamos falando de Platão, mais precisamente de sua teoria das ideias, e muito precisamente do acesso às tais ideias pelo que entendemos ser a "passividade voluntariosa" de Schopenhauer.

Voluntariosa foi a atitude de Schopenhauer ao se pretender "continuador audacioso" de Kant, antevendo no interdito deste "uma via interna aberta para nós rumo à real e interna essência das coisas (selbst-eigenen und inneren Wesen der Dinge)" (W I, 245). Ao tratar desse aspecto, mencionamos que o autor de $O$ mundo como vontade e representação fica entre a originalidade e o não convencimento. Ao valer-se da teoria das ideias de Platão, de sua atitude podemos dizer algo de quase o mesmo teor, se substituirmos "originalidade" por "excentricidade"; e ao aproximar Kant e Platão, a coisa-em-si e as ideias, a atitude de Schopenhauer tem algo mesmo de excêntrico e original:

Se para nós a Vontade é a COISA-EM-SI e as IDEIAS a sua objetidade imediata num grau determinado, encontramos, todavia, a coisa-em-si de Kant e a Ideia de Platão - único ov $\tau \omega \varsigma$ vov -, estes dois grandes e obscuros paradoxos dos dois maiores filósofos do Ocidente, de fato não como idênticas, mas como intimamente aparentadas e diferentes apenas em uma única determinação. Os dois paradoxos, que, apesar da sua afinidade interna e parentesco, soam tão diversamente em virtude das individualidades extraordinariamente diferentes de seus autores, são o melhor comentário um do outro, na medida em que se assemelham a dois caminhos completamente diferentes que conduzem a UM mesmo fim (W I, 236-237).

O “mesmo fim”, bem entendido, é a libertação da vontade e das determinações desta no âmbito da representação, da causalidade e da individuação. E sobre o referido parentesco, Schopenhauer ainda reforçará:

Se alguma vez se tivesse realmente compreendido e apreendido a doutrina de Kant e, desde o seu tempo, a de Platão; se se tivesse refletido de maneira séria e fiel sobre o conteúdo e o sentido íntimo das doutrinas dos dois grandes mestres, em vez de se ater artificialmente às expressões de um, ou à paródia estilística de outro, não teria havido demora para descobrir o quanto os dois sábios concordam e como a significação pura, o alvo de ambas as doutrinas, é exatamente o mesmo (W I, 240). 
O que Schopenhauer chama aí de "significação pura", e alhures, até com mais frequência, de uma "objetificação" (da vontade) a se dar por "puro conhecimento", e o que ele também qualifica como apreensão direta e imediata é bem o que está além de um tipo de conhecimento que ele propõe ser passível de transcender. Também aí se tem o que estamos a chamar de voluntarismo de Schopenhauer. Não se mostrasse ele voluntarista, teria se contentado com um tipo de conhecimento que se interroga apenas sobre liames causais, que versa sobre as relações dos objetos particulares, sobre as relações estabelecidas pelo princípio de razão suficiente, e isto significa, sobre relações que se dão sob a égide das formas do tempo, do espaço e da causalidade. Ocorre que para Schopenhauer é possível passar dessa circunstancialidade das coisas ao conhecimento das Ideias. De suas Ideias, se consideradas do ponto de vista que imediatamente o precedeu, o kantiano, o mais próximo que se teria seriam as ideias transcendentais - Deus, alma e mundo -, que para Kant, muito ao contrário do que se tem em Schopenhauer, ultrapassam a possibilidade de experiência, razão pela qual não podem ser conhecidas. E se assim o filósofo de Frankfurt se mostra voluntarista em comparação com a resguardada posição kantiana, Schopenhauer também o será comparativamente a Platão, com relação ao qual, ao invocar as tais Ideias, acredita e insiste na fidelidade de sua compreensão à concepção original das Ideias pelo autor d'A república, como quando afirma, "concordaremos com Platão, quando atribui um ser verdadeiro apenas às Ideias, enquanto às coisas no espaço e no tempo, a este mundo real para o indivíduo, reconhece apenas uma existência aparente e onírica” (W I, 250). E não obstante falar em "concordância” com Platão, de pronto imputa às Ideias algo de móvel, maleável e dadivoso que de modo algum está no filósofo grego. Para Schopenhauer, em sua condição de objetivação da vontade, a Ideia vai até os fenômenos: "Veremos como uma única e mesma Ideia se manifesta em grande número de fenômenos e oferece a sua essência aos indivíduos que conhecem, apenas gradualmente, um lado de cada vez” (W I, 250). Em resumo, se em Platão os objetos particulares participam da ideia, em Schopenhauer a ideia se desdobra e se espraia "nas figuras do princípio de razão [suficiente] em variados e múltiplos fenômenos” (W I, 250).

Assim, desdobramento, espraiamento... Uma Ideia que vai aos fenômenos e ali se dá a perceber. Para apreendê-la, por certo que não seria o caso de uma ascese dialética, não obstante Schopenhauer jurar fidelidade a Platão. Seria então o caso aqui de se perguntar sobre a cognição pela qual se a perceberia e sobre o sujeito apto para tal. Nesse momento, a voluntariedade de Schopenhauer, que se manifesta justamente por ele julgar possível esse conhecimento, mais uma vez conjuga-se a uma passividade, por negar a tal conhecimento qualquer operação de esforço cognitivo. Ora, vimos que toda e qualquer cognição foi de pronto excluída do domínio da vontade. O que se tem ali é o caráter direto e imediato de um "conhecimento puro", que tem o caráter de uma "contemplação" (Kontemplation, Anschauung), de uma “objetificação" (Objektivation), termo técnico de que o filósofo se vale para caracterizar a relação entre vontade e ação, que não deve passar pela 
representação nem, consequentemente, por relações causais (W I, 218-219). A relação que substitui o esforço da cognição tampouco passa pela individuação e pela subjetivação. Ao conhecer as Ideias, o sujeito se furta à servidão da vontade e de suas determinações, e uma condição para tal encontra-se na abolição de expedientes pelos quais a vontade se desdobra na instância da representação, que lhe é subordinada: esses expedientes são a razão, que para Schopenhauer é a faculdade dos conceitos e o exame das representações abstratas; o entendimento, que, pautado pelo princípio de razão suficiente, é a faculdade mesma da representação; atrelado a ambos, por fim, o canal da individualidade. Desses três expedientes liberta-se o sujeito quando se alça da representação abstrata e secundária à representação que a esta confere conteúdo e significação, qual seja, a representação intuitiva. Tem-se suprimida a subjetivação à medida que, ao chegar à contemplação estética mediante a representação intuitiva, o sujeito ele próprio se desfaz, fundindo-se ao objeto.

\section{Schopenhauer em relação com o seu tempo}

Se a vontade em Schopenhauer se fazia domada pelo próprio tratamento metafísico, a sua tematização, acompanhada da incompreensão de seu caráter e de seu significado, Nietzsche a referia como "sinal dos tempos" (cf. 25 [183], primavera de 1884) ${ }^{25}$. Segundo Nietzsche, ao tematizar a vontade Schopenhauer estaria a agir como todos os filósofos que "agem como se tivessem descoberto ou alcançado suas opiniões próprias pelo desenvolvimento autônomo de uma dialética fria, pura, divinamente imperturbável [...]: quando no fundo é uma tese adotada de antemão" (JGB/BM § 5). E se "no fundo" a tese é adotada "de antemão", isto significa que o é de modo inconsciente.

Nesse sentido, à época de Schopenhauer havia um disseminado preconceito que ele assimilou sem refletir: o preconceito contra a vontade, contra uma vontade forte (cf. 25 [183], primavera de 1884). O sinal dos tempos que o teria conduzido à sua intuição, que de forma original ele posicionou no lugar da coisa-em-si, foi uma reação contra a época napoleônica (cf. 25 [183], primavera de 1884). Napoleão era modelo humano de existência verdadeira, de identidade forte (cf. MM/HH I § 164), um modelo estoico de resistência e autonomia (cf. 2 [42], primavera de 1880), modelo também de penetração e tenacidade (cf. 8 [118], inverno de 1880-1881), de devoção a si, à sua vontade, a seus interesses (cf. 7 [275], final de 1880). Pois a época em que Schopenhauer concebe a sua ideia de vontade é já um momento de reação a esse contexto, um momento em que "já não se acredita na 'força de vontade"” (25 [183], primavera de 1884), ou seja, um momento de vontade esmorecida. E o autor de $O$ mundo... não teria se mostrado imune à irreflexão dos filósofos que os faz reféns

\footnotetext{
25 “Quero uma vez mostrar como a má compreensão da vontade por Schopenhauer é um 'sinal dos tempos' - é a reação contra os tempos napoleônicos, já não se acreditam em heróis, isto é, na força da vontade” (25 [183], primavera de 1884).
} 
da relação de inversão a contrapor força e proximidade de um determinado quadro, por um lado, e a possibilidade de sua compreensão e tematização, assim prejudicada ou impossibilitada, por outro. Essa contraposição, que também pode ser entendida no sentido inverso, de algo que se torna visível e tematizável justamente porque arrefecido, Nietzsche a traz à luz em Para além de bem e mal: recorrendo à alegoria, observa a relação direta entre deter as mais amplas perspectivas e manter-se afastado (cf. JGB/BM § 129), ou seja, entre distanciamento e capacidade de visualização; essa contraposição é sugerida também nas referências à relação entre revelação e declínio (cf. JGB/BM § 130), como pode ser depreendida da relação entre falar e ocultar (cf. JGB/BM § 169); e numa alegoria ainda mais direta e clara, tem-se o escrever e pintar somente o que já murchou, perdeu o aroma, ou que está a ponto de fazê-lo (JGB/BM § 296), e este, enfim, é bem o caso da vontade à época de Schopenhauer. À força de contraposições como essas Schopenhauer sucumbe de maneira irrefletida, em vez de haurir a potência que elas poderiam liberar: nele a vontade surgiu como um aparente oposto, que se deu a tematizar justamente por se estar muito à distância dele, como o que se dá a revelar por ter perdido aroma e viço; afinal, tida como torturante e indiferente, a vontade fora considerada boa havia não muito tempo, no aristocrático século XVII (cf. 9 [178], outono de 1887). Assim, a tematização da vontade teria sido tal qual o referido ódio travestido de amor, seria mais sua afetação do que sua presença - afeta-se uma afinidade com ela, como o amante afeta no outro o amor que sente por si mesmo -; dela se fala, por fim, para se ocultar o quanto dela se carece.

Schopenhauer, em que pese se fazer joguete inconsciente dessas oposições e por elas pautar sua filosofia, em algum nível de sua constituição captava e sabia que num certo âmbito, mais profundo em relação ao que se mostra, não seria disparatado falar nessas relações, tampouco elas, se se mostrassem em seu jogo de compensações, iriam se revelar opostas. Pelo contrário, poriam à mostra seu acobertado compromisso, seu entremeio, seu recíproco fomento. Esse âmbito é o da instintualidade, o da animalidade, dos apetites, e assim como Rousseau se apercebeu do domínio do sentimento, prestes a aflorar pela Europa, no que se antecipou a ele e à sensibilidade romântica, também Schopenhauer, muito à sua maneira, antecipou-se ao desvelamento dos instintos e à animalidade do homem. Nietzsche, ao ladear os séculos XVII, XVIII e XIX, arrola sobre o XIX: "animalismo Schopenhauer, domínio dos apetites, testemunho da soberania da animalidade" (9 [178], outono de 1887) ${ }^{26}$. Ora, essa associação, bem como a aproximação da animalidade em relação a um domínio que até então lhe era avesso, de modo algum é intempestiva, muito menos casual. Associação e aproximação podem e devem ser

${ }^{26}$ Em outra (e única) ocorrência a associar Schopenhauer à animalidade, mais precisamente a uma constituição selvagem, o autor de Aurora faz referência a aspectos biográficos - que em Nietzsche, como sabemos, jamais se resumem ao meramente biográfico: "uma certa veemente feiura da natureza [de Schopenhauer], em ódio, cobiça, desconfiança, vaidade, é de constituição um tanto mais selvagem e tinha tempo e vagar para esta selvageria” (M/A § 481). 
compreendidas mediante os feitos da própria racionalidade a contar da revolução científica dos séculos XVI e XVII: com Galileu, o mundo se revela muito maior do que se pensava que fosse e, o que é mais importante, sem a cesura fundamental entre as esferas sublunar, onde havia ordenamento, mas também contingência, e supralunar, esfera de entes individualmente eternos, de necessidade e harmonia. Com isso se evidenciava que o mundo dos seres humanos não seria inferior ou menos perfeito que o supralunar. Ao mesmo tempo, com Copérnico se revelava que a Terra não estava no centro do Sistema Solar. O travejamento do inteiro Universo por leis segundo Newton logo viria a pôr em risco a possibilidade da liberdade humana, a relevância de sua moralidade e, com isso, de sua condição tal como até então se a conhecia. Ato contínuo, Kant tratou de abrir uma clareira para que vicejasse a questão da liberdade, da moralidade, porém isso à custa de limitar o poder da razão no tocante ao acesso às coisas mesmas. Paralelamente, o modelo e os progressos da física newtoniana foram imitados por outros campos do saber, como o da biologia, da fisiologia, da citologia. A respeito dessas disciplinas, justamente, as lentes empregadas para a visualização do infinitamente grande, nos séculos XVI e XVII, passaram a sê-lo também para o infinitamente pequeno, nos XVIII e XIX. No bojo das ciências da vida, elas logo viriam a desvelar uma perspectiva na qual as diferenças entre o homem e outros animais, e mesmo em relação aos seres orgânicos em geral, não seria tão grande, mas sim seria de grau e dependeria de um fator pelo qual ainda se tateava ${ }^{27}$.

Entretanto, a posição de Schopenhauer em meio a esse processo não se deu sem a contribuição, afinal... do próprio Schopenhauer. Temos visto que a leitura de Nietzsche sobre certas "escolhas" dos filósofos desce a um estrato mais profundo que o da letra expressa, e nesse estrato ele encontra um filósofo em comunalidades insuspeitadas, em meio a tipologias que sequestram virtuais singularidades, sendo tipologias que afloram num determinado povo, em determinada época, e entram em recesso para reaparecer sob circunstâncias semelhantes, como traços atávicos. É fato que o mais das vezes um filósofo pode sucumbir à inclinação de seu tempo, e que Nietzsche faz exortações para uma atuação em sentido contrário (cf. 19 [12], verão de 1872 - início de 1873). Um filósofo pode irrefletidamente aderir ao ambiente otimista da primeira metade do século XIX, como pode sucumbir ao pessimismo reinante na segunda metade. Como pode ficar preso ao embate entre um e outro, este que o autor do Zaratustra tem por superficial. Quanto aos dois ambientes, Schopenhauer conviveu em ambos, entabulando uma relação peculiar com cada um deles, cada qual a seu momento. Mesmo em meio ao otimismo hegeliano da primeira metade do século, quando os homens órfãos de Deus sem mais inseriam sombras divinas em seu próprio filosofar, compensando a derrocada teológica com seu absoluto, com a teleologia da história, a isso Schopenhauer respondeu como homem nobre, de

\footnotetext{
${ }^{27}$ Sobre a formação do pensamento biológico num momento imediatamente anterior a Schopenhauer, ou seja, em Kant, cf. em toda a sua extensão, MARQUES, U. R. A. (org.) Kant e a biologia. São Paulo: Barcarolla, 2012.
} 
postura autônoma, dono de uma peculiar medida de valor (cf. FW/GC § 3, onde, porém, não há referência específica a Schopenhauer). Respondeu com o que Nietzsche observa ser "sua limpeza em questões da Igreja e do Deus cristão" (FW/GC § 99), com "seu duro senso dos fatos, sua honesta vontade de clareza e razão [...] ou [com] o vigor de sua consciência intelectual, que toda a vida suportou a contradição entre ser e querer” (FW/GC § 99). Com isso ele se contrapôs às inclinações de seu tempo. E em relação à segunda metade do século, com seu mal-estar quanto à condição humana, Schopenhauer foi antecipador. Se na primeira metade a Europa ainda conseguiu preferir a identificação entre razão e mundo, de Hegel, e a crença positiva no curso da história, o fracasso das revoluções de 1848 fez o europeu finalmente se dar conta da impotência de sua própria condição. O colapso da crença em Deus não seria compensado pela versão "Primavera dos Povos” de realização das possibilidades do agir humano. Com a desesperança e o pessimismo reinantes, não por acaso a publicação dos Parerga e parelipomena, em 1851, ao contrário do que fora a da primeira edição de $O$ mundo como vontade e representação, em 1818, fez-se rápida disseminação e estrondoso sucesso: a Europa reconhecia a sua impotência e passava a se reconhecer em Schopenhauer, onde, segundo vimos aqui, o impulso vital esmaecido visibilizou-se e se deu a tematizar.

\section{Animalidade em filosofia}

Para Nietzsche, mais nítida e mais cruamente do que Rousseau, Schopenhauer "viu” a sua própria animalidade. Esteve em aberto contato com seu lado animal e selvagem, que se dava, porém, como lado selvagem resultante de seu aprisionamento pelas convenções e normas sociais - como as que regem relações que foram tão problemáticas para Schopenhauer, e entenda-se, entre homem e mulher e as acadêmicas ${ }^{28}$. Schopenhauer até mesmo trouxe essa animalidade à filosofia. Porém, sem dispor de meios científicos para acessar as profundezas animais que em si já vislumbrava ${ }^{29}$ - as ciências da vida

\footnotetext{
${ }^{28} \mathrm{~A}$ outra (e única) ocorrência a associar Schopenhauer à animalidade (além do fragmento 9 [178], do outono de 1887), mais precisamente a uma "constituição selvagem", versa justamente sobre aspectos biográficos que em Nietzsche, como sabemos, jamais se resumem ao meramente biográfico: "uma certa veemente feiura da natureza, em ódio, cobiça, desconfiança, vaidade, é de constituição um tanto mais selvagem e tinha tempo e vagar para esta selvageria” (M/A § 481).

${ }^{29}$ As restrições aqui referidas dizem respeito tão-somente ao estágio das diversas ciências em seu tempo, momento em que estavam "se desprendendo" da filosofia naturalis, uma vez que o interesse de Schopenhauer pelos vários campos do saber, que logo se tornariam ciências, era quase tão intenso e devidamente exercido quanto será mais tarde, com as ciências de seu tempo, o de Nietzsche. A esse respeito, cf. ZAMBONINI, F. Schopenhauer e lascienza moderna discorso per la solene inaugurazione dell'anno accademico dela Reale Università di Sassari. Sassari: Tip. Dita G. Dess, 1911. SEgALA, M. Philosophie de la Nature et science chez Schopenhauer. In: Schopenhauer - Nouvelles Lectures. Les Études Philosophiques, p. 389-408 e BOZICKOVIC, V. Schopenhauer on Scientific Knowledge. In: VANDENABEELE, B. A Companion to Schopenhauer, p. 11-24.
} 
conheceriam um avanço formidável no período que separa Schopenhauer e Nietzsche - e sem chancelas morais para fazê-lo de fato em sua filosofia, Schopenhauer embotou e aprisionou a animalidade no homem do modo como aqui procuramos trazer à luz. A hesitação de Schopenhauer, Nietzsche a atribui à defensividade de sua "segunda natureza" (26 [285], verão-outono de 1884) - a alemã - em relação ao emergir da primeira - a natureza animal. Pela tal "segunda natureza", em Schopenhauer fez-se possível uma identificação inquestionada à representação em detrimento da vontade; como se, ao que observará Nietzsche, certas representações fossem possíveis sem a relação com um querer, e como se a vontade não fosse um impulso a conter em si "a representação da existência de um objeto de satisfação" (9 [1], verão de 1875). Tivesse atentado a isso, Schopenhauer talvez se questionasse sobre se não caberia um questionamento a apontar para alguma identificação justamente com aquela vontade, com aquela "primeira natureza”. Pela desatenção a seus próprios processos inconscientes, foi possível a Schopenhauer deixar de vivenciar por sentir antecipadamente e, de modo paradoxal, em demasia. Foi-lhe possível esquivar-se, fazer a vontade se voltar contra $\mathrm{si}^{30}{ }^{30}$ e fazer de si próprio um espectador. Um torturado espectador do mundo e de sua filosofia.

\section{Referências}

ASSOUN, P.-L. Freud et Nietzsche. Paris: Presses Universitaires de France, 1998.

ASSOUN, P.-L. Freud - La philosophie et les philosophes. Paris: Presses Universitaires de France, 1976.

BOZICKOVIC, V. Schopenhauer on Scientific Knowledge. In: VANDENABEELE, B. $A$ Companion to Schopenhauer. Malden, MA: Wiley-Blackwell, 2012, p. 11-24.

GARDNER, S. Schopenhauer Will and the Unconscious. In: JANAWAY, C. The Cambridge Companion do Schopenhauer. Cambridge: Cambridge, University Press, 1999, p. 375-421.

GÖDDE, G. Traditionslinien des “Unbewußten”. Schopenhauer - Nietzsche - Freud. Gießen: Psychosocial-Verlag, 2009.

KRIEGER, S. O cerne oculto do projeto nietzschiano: logos versus pathos no ato de filosofar. Tese apresentada ao Programa de Pós-Graduação em Filosofia da Escola de Filosofia, Ciências Humanas e Letras da Universidade Federal de São Paulo (Unifesp) em abril de 2019.

\footnotetext{
30 "No pano de fundo da última filosofia a aparecer, a schopenhaueriana, tem-se, quase que como problema em si, esse pavoroso ponto de interrogação da crise e do despertar religiosos. Como é possível essa negação da vontade? Como é possivel o sagrado? - Essa parece realmente ter sido a pergunta que Schopenhauer se fez e pela qual se tornou filósofo" (JGB/BM § 47).
} 
JACQUETTE, D. Schopenhauer's Proof that Thing-in-Self is Will. Kantian Review, 12, 2006, p. 65-108.

JANAWAY, C. Introduction. In: JANAWAY, C. The Cambridge Companion to Schopenhauer. Cambridge: Cambridge University Press, 1999, p. 1-17.

MARQUES, U. R. A. (org.) Kant e a biologia. São Paulo: Barcarolla, 2012.

NIETZSCHE. F. Werke. Kritische Gesamtausgabe (KGW). Berlin/New York: Walter de Gruyter, 1967-1978.

NIETZSCHE. F. Werke. Kritische Studienausgabe (KSA). Berlin/New York: Walter de Gruyter, 1999.

NIETZSCHE. F. A gaia ciência. Trad. Paulo César de Souza. São Paulo: Companhia das Letras, 2011.

NIETZSCHE. F. Além do bem e do mal. Trad. Paulo César de Souza. São Paulo: Companhia das Letras, 1999.

NIETZSCHE. F. Além do bem e do mal. Trad. Saulo Kriger. São Paulo: Edipro, 2019

NIETZSCHE. F. Aurora. Trad. Paulo César de Souza. São Paulo: Companhia das Letras, 2008.

NIETZSCHE. F. Ecce homo. Trad. Paulo César de Souza. São Paulo: Companhia das Letras, 2011.

NIETZSCHE. F. Humano, demasiado humano I. Trad. Paulo César de Souza. São Paulo: Companhia das Letras, 2012.

NIETZSCHE. F. Humano, demasiado humano II. Trad. Paulo César de Souza. São Paulo: Companhia das Letras, 2008.

NIETZSCHE. F. O nascimento da tragédia. Trad. Jacob Guinsburg. São Paulo: Companhia das Letras, 2012.

SCHENZ, A. Erlebnis und Bildung. Die Bedeutung des Erlebens und des Erlebnisses in Unterrichts- und Erziehungsprozessen. Karlsruhe: Universitätsverlag Karlsruhe, 2007.

SCHOPENHAUER, A. Die Welt als Wille und Vorstellung. Zweiter Band. München: Georg Müller, 1913 (W II).

SCHOPENHAUER, A. O mundo como vontade e como representação. Trad. Jair Barboza. São Paulo: Editora Unesp, 2005 (W I).

SEGALA, M. Philosophie de la Nature et science chez Schopenhauer. In: Schopenhauer Nouvelles Lectures. Les Études Philosophiques, 2012/3, no 102, p. 389-408. 
SOLL, I. Schopenhauer as Nietzsche's 'Great Teacher' and 'Antipode'. In: GEMES K. \& RICHARDSON, J. The Oxford Handbook of Nietzsche. Oxford: Oxford University Press, 2013.

SOMMER, A. U. O que Nietzsche leu e o que não leu. Trad. Saulo Krieger. Cadernos Nietzsche, São Paulo, v. 40 n. 1, janeiro/abril 2019, p. 9-43.

VIESENTEINER, J. L. O conceito de vivência (Erlebnis) em Nietzsche. Gênese, significado e recepção. Kriterion, Belo Horizonte, n. 127, junho 2013, p. 141-155.

ZAMBONINI, F. Schopenhauer e la scienza moderna: discorso per la solene inaugurazione dell'anno accademico della Reale Università di Sassari. Sassari: Tip. Dita G. Dess, 1911. 